\title{
New Approach for the Stereoselective Synthesis of (+)-epi-Cytoxazone
}

\author{
Izabel L. Miranda, ${ }^{a}$ Suélen K. Sartori, ${ }^{a}$ Marisa A. N. Diaz ${ }^{b}$ and Gaspar Diaz-Muñoz ${ }^{\odot *, a}$ \\ ${ }^{a}$ Departamento de Química, Universidade Federal de Minas Gerais, \\ 31270-901 Belo Horizonte-MG, Brazil \\ ${ }^{b}$ Departamento de Bioquímica e Biologia Molecular, Universidade Federal de Viçosa, \\ 36570-900 Viçosa-MG, Brazil
}

\begin{abstract}
The stereoselective total synthesis of $(+)$-epi-cytoxazone was performed satisfactorily in 8 steps, in $17 \%$ overall yield, via a novel route from 2,3- $O$-(3-pentylidene)- $(R)$-glyceraldehyde. The bulky group alkene-ketal allowed intramolecular control of the target molecule's asymmetric centers in the dihydroxylation step by promoting the approach of $\mathrm{OsO}_{4}$ to the face opposite to that of the ketal group.
\end{abstract}

Keywords: cytoxazone, epi-cytoxazone, 2,3-O-(3-pentylidene)-( $R$ )-glyceraldehyde, Wittig olefination, stereoselective dihydroxylation

\section{Introduction}

Oxazolidinones comprise a class of natural and synthetic compounds that exhibit antibacterial activity against a wide range of Gram-positive bacteria, ${ }^{1,2}$ such as methicillin- and vancomycin-resistant Staphylococci, vancomycin-resistant Enterococci, and penicillin-resistant anaerobes and Pneumococci. However, oxazolidinones have limited efficacy against Gram-negative bacteria. ${ }^{2}$ Their mechanism of action, although not fully understood, is thought to be initiated by inhibition of the early stages of protein synthesis. ${ }^{1}$

New synthetic antimicrobial agents were discovered by DuPont researchers from a library of compounds containing the oxazolidin-2-one nucleus, analogous to that of (-)-cytoxazone (Figure 1), ${ }^{3,4}$ These compounds exhibited high bacteriostatic effect on human pathogenic bacteria in in vitro and in vivo tests. ${ }^{3}$

Although natural sources of compounds that contain the oxazolidin-2-one nucleus are very rare, ${ }^{5}$ Kakeya et al. ${ }^{6}$ were able to isolate a novel compound belonging to this class, $(4 R, 5 R)$-5-hydroxymethyl-4- $p$-methoxyphenyl1,3-oxazolidin-2-one, ((-)-cytoxazone, Figure 1), from Streptomyces bacteria. Nakata and co-workers ${ }^{7}$ and Mori and $\mathrm{Seki}^{8}$ performed the first asymmetric total syntheses of (-)-cytoxazone and thus confirmed its absolute configuration.

*e-mail: gaspardm@qui.ufmg.br

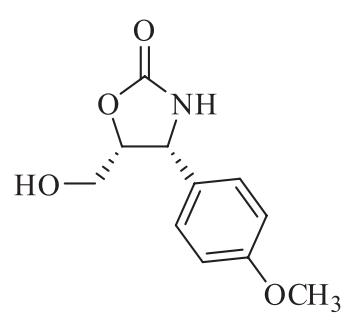

Figure 1. Chemical structure of (-)-cytoxazone.

(-)-Cytoxazone is a natural product that is important for the therapeutic arsenal currently available to treat many diseases. An example of its importance lies in its cytokinemodulating effect, associated with immunotherapeutic activities, as reported by Kakeya et al. ${ }^{9}$

Discovery of the biological potentialities of cytoxazone by Kakeya's research group has leveraged the development of studies aimed at the synthesis of this compound, which is evidenced by the large number of publications on this topic, addressed in two important reviews published by Zappia et $a l .{ }^{5}$ and Miranda et al. ${ }^{10}$

Like cytoxazone, 4-epi- and 5-epi-cytoxazone epimers have attracted the attention of the scientific community because of their pharmacological properties. Some interesting examples are given in racemic and enantioselective synthesis studies. ${ }^{11-16}$

Lu et al..$^{12}$ developed a new protocol for the synthesis of ( \pm )-epi-cytoxazone that consists of a cascade of organocatalytic reactions between a sulfur ylide and a 
nitroolefin catalyzed by thiourea and 4-( $N, N$-dimethylamino) pyridine (DMAP).

Smitha and Reddy ${ }^{13}$ synthesized (+)-epi-cytoxazone in six steps, starting from anisaldehyde and using Sharpless kinetic resolution followed by Mitsunobu inversion to obtain the target molecule with the desired stereochemistry.

In a recent publication, Matsushima et al. ${ }^{16}$ reported the synthesis of (-)-epi-cytoxazone through an oxazoline intermediate, whose formation was based on the intramolecular benzylic substitution of 1,2-bis-trichloroacetimidate obtained from the respective enantiomerically pure diol.

The present study describes the stereoselective total synthesis of the non-natural oxazolidinone epi-cytoxazone (1), motivated by the compound's biological importance, given that this stereoisomer had higher activity than its natural counterpart, (-)-cytoxazone, in antibacterial assays against Gram-positive Bacillus subtilis and Gram-negative Escherichia coli. ${ }^{17}$ epi-Cytoxazone (1) was obtained in eight steps by means of a novel synthetic route that uses the small chiral building block of 2,3-O-(3-pentylidene)-( $R$ )-glyceraldehyde (2) to control the stereocenters of the target molecule.

In this study, we proposed that 5-epi-cytoxazone (1) may be prepared by an $\mathrm{N}, \mathrm{O}$-heterocyclization reaction of the corresponding amino alcohol $(\mathbf{8})$ in the last step of the synthesis (Scheme 1). The key intermediate $\mathbf{8}$ can be obtained by means of an amination reaction, which consists in the regioselective opening of the sulfite ring (6) with sodium azide and inversion of the stereocenter, followed by the reduction of this group in the resulting azido alcohol. In turn, sulfite (6) can be readily prepared by a sulfocyclization reaction of diol $\mathbf{5}$. We also observed that diol $\mathbf{5}$ can be obtained by stereoselective dihydroxylation of alkene $\mathbf{4}$, in which the control of the asymmetric centers of the corresponding diol can be achieved by the induction exerted by the chiral core units of the pentylidene ketal. Further analysis indicated that alkene $\mathbf{4}$ can be derived from the Wittig olefination reaction between $(R)$-glyceraldehyde ketal (2) and the corresponding ylide, generated from 3.

\section{Results and Discussion}

The synthesis of 5-epi-cytoxazone (1) started with the preparation of $(R)$-glyceraldehyde ketal (2) from D-mannitol, following a known protocol ${ }^{18}$ with some modifications (see Experimental section). To avoid or minimize its racemization, $(R)$-glyceraldehyde ketal (2) was immediately subjected to the Wittig olefination step by treatment with (4-methoxybenzyl)triphenylphosphonium chloride (3) and $t$ - $\mathrm{BuOK}$ as the base in a $\mathrm{CH}_{2} \mathrm{Cl}_{2} / t-\mathrm{BuOH}$ mixture (1:1) (phase transfer medium), a protocol recently developed by our research group ${ }^{19}$ to give an $E / Z$ mixture of 4 in $85 \%$ yield (three steps from D-mannitol) (Scheme 2). Separation of the isomers by column chromatography confirmed the 4:1 preferential formation of the Z-olefin.

The stereochemistry of the Z-olefin (4) was confirmed by analyzing its ${ }^{1} \mathrm{H}$ nuclear magnetic resonance (NMR) spectrum and observing the coupling constant ${ }^{3} J 11 \mathrm{~Hz}$ relative to the adjacent $\mathrm{H}_{4}$ and $\mathrm{H}_{5}$ of the olefinic double bond (sequential numbering from the epi-cytoxazone ring), which suggested that these hydrogens are on the same side of the double bond. This finding was corroborated by nuclear Overhauser spectroscopy (NOESY) interaction
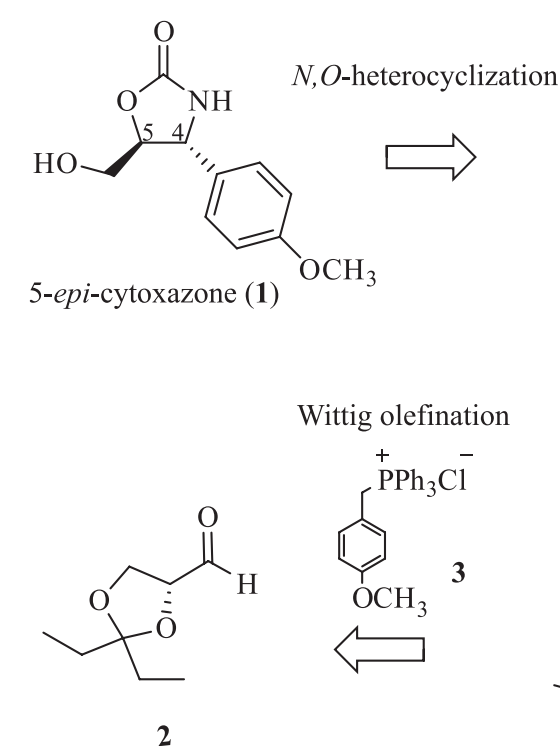

Wittig olefination

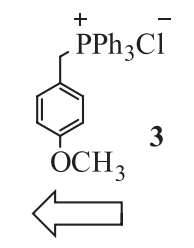

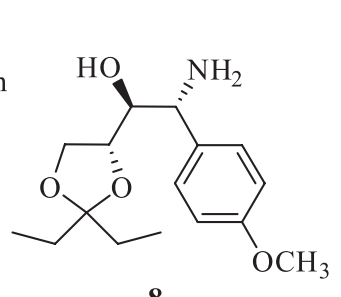

8

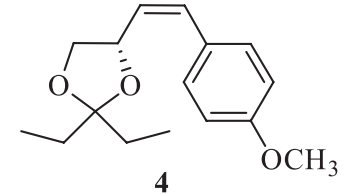

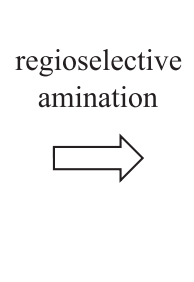

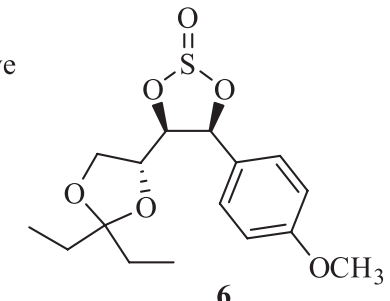

$\downarrow$ sulfocyclization

stereoselective dihydroxylation
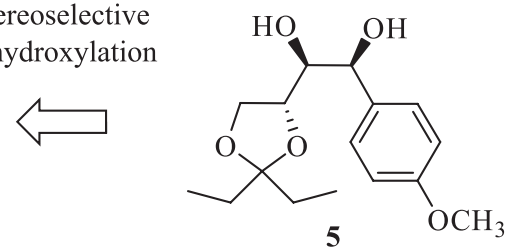

Scheme 1. Retrosynthetic analysis of (+)-epi-cytoxazone (1) from (R)-glyceraldehyde ketal (2). 


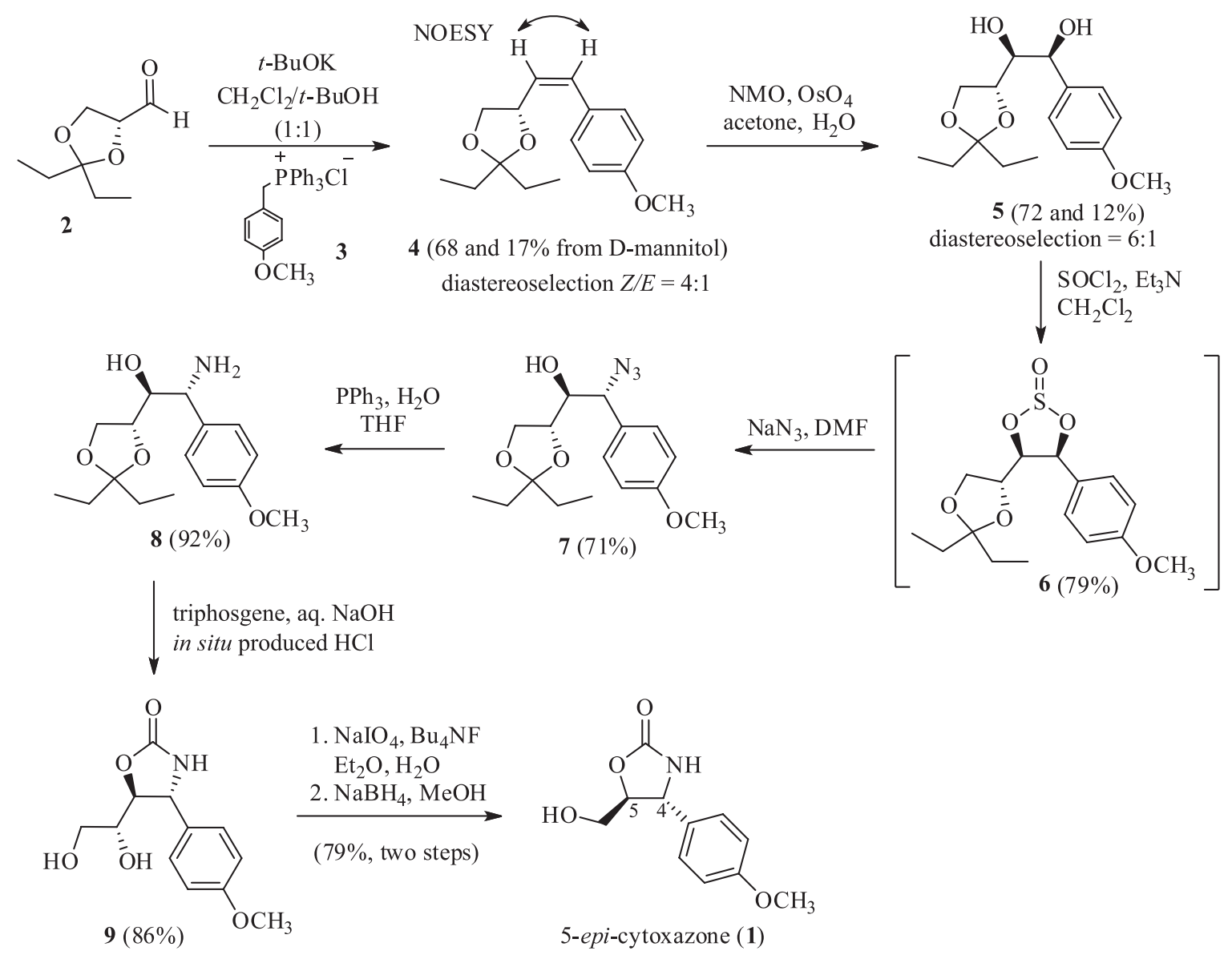

Scheme 2. Synthetic route of 5-epi-cytoxazone (1).

between these protons. In contrast, the ${ }^{1} \mathrm{H}$ NMR spectrum of the $E$-olefin showed a coupling constant $\left({ }^{3} J_{\mathrm{H} 4-\mathrm{H} 5}\right)$ of $15.8 \mathrm{~Hz}$.

Subsequently, the major olefin (4) was subjected to a stereoselective dihydroxylation reaction by using $\mathrm{OsO}_{4}$ and 4-methylmorfoline $\mathrm{N}$-oxide (NMO) to obtain diol $\mathbf{5}$ (referred hereafter as anti-diol).

Cha et al..$^{20}$ obtained high anti-stereoselectivity in dihydroxylation reactions of olefins containing a chiral acetal unit using $\mathrm{OsO}_{4}$. According to the authors, the experimental results indicate that the diols formed are mainly those obtained by the approach of $\mathrm{OsO}_{4}$ to the face opposite to that of the acetonide group (anti-diol).

On the basis of this last work, we prepared $(R)$-glyceraldehyde ketal (2), but we increased the steric volume of the ketal unit by replacing the methyl substituents used by Cha et al. ${ }^{20}$ with ethyl groups in search of greater diastereoselectivity in the dihydroxylation of $\mathbf{4}$ in favor of the anti-diol (5).

This proposal was consistent with that reported by Cha et al. ${ }^{20}$ and was confirmed by obtaining anti-diol $\mathbf{5}$ as the major product, as predicted, in the ratio of 6:1.

After optimization of the elution system, the diastereoisomeric mixture of the anti-diol (5) and its syn diastereoisomer was separated by column chromatography using hexane/ethyl acetate (75:25). The anti-diol (5) and its diastereoisomer were obtained in 72 and $12 \%$ yield, respectively.

Next, the anti-diol (5) was treated with triethylamine in the presence of thionyl chloride, affording the respective cyclic sulfite (6) in $79 \%$ yield.

Cyclic sulfites are a powerful tool in the control of the stereoselectivity of adjacent chiral diols, being considered very versatile electrophilic synthons, synthetically equivalent or superior to epoxides against several nucleophiles. ${ }^{21,22}$

Sulfite 6 was immediately submitted to the next step, without previous purification, because of its high reactivity, thus avoiding degradation. The regioselective opening of the ring of $\mathbf{6}^{7,8}$ using sodium azide gave azido alcohol 7 , which, after reduction of the azide group by treatment with $\mathrm{PPh}_{3} / \mathrm{H}_{2} \mathrm{O},{ }^{23}$ produced amino alcohol 8 in $56 \%$ yield (two steps). The preferential opening of sulfite $\mathbf{6}$ at the benzyl carbon is probably due to the electron-withdrawing effect exerted by the aromatic ring, associated with the steric hindrance of the bulky ketal group adjacent to carbon-5.

$\mathrm{N}, \mathrm{O}$-Heterocyclization of $\mathbf{8}$ employing triphosgene, with concomitant hydrolysis of the acetal group by $\mathrm{HCl}$ formed 
in situ, obviated the need for a subsequent deprotection step, directly providing oxazolidinone derivative 9 in $86 \%$ yield.

Finally, oxidative cleavage of diol 9 employing $\mathrm{NaIO}_{4}$ and reduction of the resulting aldehyde with $\mathrm{NaBH}_{4}$ afforded 5-epi-cytoxazone (1), which exhibited a specific rotation of $[\alpha]_{\mathrm{D}}{ }^{26.7}+27.5^{\circ}\left(c 0.4, \mathrm{CH}_{3} \mathrm{OH}\right)$, in agreement with literature data $^{13,24-26}\left\{[\alpha]_{\mathrm{D}}^{25}+28.8^{\circ}\left(c 0.59, \mathrm{CH}_{3} \mathrm{OH}\right),[\alpha]_{\mathrm{D}}^{25}+32^{\circ}(c 0.4\right.$, $\left.\left.\mathrm{CH}_{3} \mathrm{OH}\right),[\alpha]_{\mathrm{D}}^{25}+22.89^{\circ}\left(c 0.4, \mathrm{CH}_{3} \mathrm{OH}\right)\right\}$, in $79 \%$ yield (two steps). In addition to determining the stereochemistry of the 5-epi-cytoxazone isomer, these results confirmed that the synthetic strategy adopted prevented the racemization of $(R)$-glyceraldehyde ketal (2).

The relative stereochemistry of trans-oxazolidinone 1 was unequivocally established by analysis of the ${ }^{1} \mathrm{H}$ NMR spectrum. The coupling constant $\left({ }^{3} J_{\mathrm{H} 4-\mathrm{H} 5} 6.4 \mathrm{~Hz}\right)$ indicates that these hydrogens are on opposite faces of the heterocyclic ring ${ }^{27-30}$ (Figure 2). Spectroscopic data of this stereoisomer are totally in agreement with those reported in the literature. ${ }^{13,24-26}$

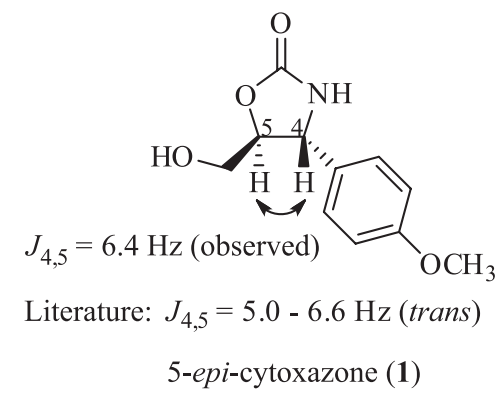

Figure 2. Analysis of the coupling constant and determination of the relative stereochemistry of $\mathbf{1}$.

\section{Conclusions}

Synthesis of 5-epi-cytoxazone (1) was performed in 8 steps from $(R)$-glyceraldehyde ketal $(2)$ in $17 \%$ overall yield by means of a novel and stereoselective synthetic route. Induction of stereoselectivity in the dihydroxylation step was performed intramolecularly from alkene-ketal 4, as $\mathrm{OsO}_{4}$ approaches preferentially the face opposite to that of the ketal group, which made it possible to control the asymmetric centers of the target molecule. Additional studies on (+)- and (-)-cytoxazone synthesis based on this strategy are underway in our laboratory and will be published later.

\section{Experimental}

\section{General procedures}

${ }^{1} \mathrm{H}$ and ${ }^{13} \mathrm{C}$ NMR spectra were recorded on Bruker Avance and Bruker DPX Avance spectrometers at 400 and
$100 \mathrm{MHz}$ and 200 and $50 \mathrm{MHz}$, respectively. The liquid chromatography tandem-mass spectrometry (LC-MS/MS) analyses were performed on a Shimadzu Nexera UHPLC-system coupled to a Bruker maXis ETD high-resolution electrospray-ionization quadrupole time-of-flight mass spectrometer (ESI-QTOF). Infrared (IR) spectra were recorded on an FTIR spectrometer with a diamond attenuated total reflectance (ATR) accessory as a thin film. Melting points were measured in open capillary tubes using a Microquimica (MQAPF-302) digital melting point apparatus and were not corrected. Purification by column chromatography was performed on silica gel (70-230 or 230-400 mesh). Thin layer chromatography (TLC) visualization was achieved by spraying with $5 \%$ ethanolic phosphomolybdic acid and subsequent heating. Tetrahydrofuran (THF) and ethyl ether were distilled from sodium metal and benzophenone ketyl under nitrogen. Dimethylformamide (DMF), triethylamine $\left(\mathrm{Et}_{3} \mathrm{~N}\right)$ and dichloromethane $\left(\mathrm{CH}_{2} \mathrm{Cl}_{2}\right)$ were distilled from $\mathrm{CaH}_{2}$. Acetonitrile was dried over $4 \AA$ molecular sieves $(24 \mathrm{~h})$ and distilled from $1 \%(\mathrm{~m} / \mathrm{v}) \mathrm{P}_{2} \mathrm{O}_{5} . t-\mathrm{BuOH}$ and $\mathrm{MeOH}$ were distilled from $\mathrm{Mg}(\mathrm{O} t-\mathrm{Bu})_{2}$ and $\mathrm{Mg}\left(\mathrm{OCH}_{3}\right)_{2}$. All chemicals were used as received unless otherwise stated.

\section{Synthesis}

(R)-2,2-Diethyl-1,3-dioxolane-4-carbaldehyde (2)

D-Mannitol (5.0 g, $27.45 \mathrm{mmol})$, DMF (25 mL), camphorsulfonic acid $(0.25 \mathrm{~g}, 0.686 \mathrm{mmol})$, and 3,3-dimethoxypentane $(9.07 \mathrm{~g}, 68.63 \mathrm{mmol})$ were added to a $100 \mathrm{~mL}$ flask. The mixture was kept under stirring at room temperature and inert atmosphere for $24 \mathrm{~h}$. After this reaction period, ethyl ether $(25 \mathrm{~mL})$ and saturated $\mathrm{NaHCO}_{3}$ solution $(25 \mathrm{~mL})$ were added to the flask, and the organic phase was then separated. The aqueous phase was further extracted with ethyl ether $(2 \times 30 \mathrm{~mL})$. The combined organic phases were washed with saturated $\mathrm{NaCl}$ solution, dried over anhydrous $\mathrm{Na}_{2} \mathrm{SO}_{4}$, and concentrated under reduced pressure, yielding $(1 S, 2 S)$-1,2-bis[ $(R)$-2,2-diethyl1,3-dioxolan-4-yl]ethane-1,2-diol as a white solid in good purity, which was used in the next step without further purification. $[\alpha]_{\mathrm{D}}{ }^{26.7}+7.6^{\circ}\left(c\right.$ 5.0, $\left.\mathrm{CH}_{3} \mathrm{OH}\right)$; $\left\{\right.$ lit. ${ }^{31}$ $\left.[\alpha]_{\mathrm{D}}{ }^{25}+7.8^{\circ}\left(c 5.0, \mathrm{CH}_{3} \mathrm{OH}\right)\right\}, \operatorname{mp} 87.9-88.4{ }^{\circ} \mathrm{C} ;{ }^{1} \mathrm{H} \mathrm{NMR}$ $\left(400 \mathrm{MHz}, \mathrm{CDCl}_{3}\right) \delta$ 4.20-4.10 (m, 4H), 3.97-3.87 $(\mathrm{m}, 2 \mathrm{H}), 3.76(\mathrm{t}, J 6.3 \mathrm{~Hz}, 2 \mathrm{H}), 2.72(\mathrm{~d}, J 6.7 \mathrm{~Hz}, 2 \mathrm{H})$, $1.71-1.57$ (m, 8H), 0.94-0.85 (m, $12 \mathrm{H}) ;{ }^{13} \mathrm{C}(100 \mathrm{MHz}$, $\left.\mathrm{CDCl}_{3}\right) \delta 113.49,76.46,71.82,67.57,29.79,23.13$, 8.40, 8.22; HRMS (ESI-TOF) $m / z$, calcd. for $\mathrm{C}_{16} \mathrm{H}_{30} \mathrm{NaO}_{6}$ $[\mathrm{M}+\mathrm{Na}]^{+}:$341.1935; found: 341.1938. In another $100 \mathrm{~mL}$ flask, the corresponding diketal $(0.527 \mathrm{~g}, 1.65 \mathrm{mmol})$, tetrabutylammonium fluoride $(0.009 \mathrm{~g}, 0.036 \mathrm{mmol})$, ethyl 
ether $(6 \mathrm{~mL})$ and distilled water $(3 \mathrm{~mL})$ were combined. Thereafter, sodium periodate $(0.765 \mathrm{~g}, 3.3 \mathrm{mmol})$ was added in small portions over $20 \mathrm{~min}$, and the mixture was kept under constant stirring at room temperature for $4 \mathrm{~h}$. Then, saturated $\mathrm{NaHCO}_{3}$ solution $(10 \mathrm{~mL})$ was added and extracted with ethyl acetate $(3 \times 15 \mathrm{~mL})$. The organic phases were washed with brine, dried over anhydrous $\mathrm{Na}_{2} \mathrm{SO}_{4}$, and concentrated under reduced pressure, providing the respective $(R)$-glyceraldehyde ketal $(2)$, which was used in the next step without prior purification in order to avoid its racemization.

\section{(4-Methoxybenzyl)triphenylphosphonium chloride (3)}

Triphenylphosphine $(2.17 \mathrm{~g}, 8.29 \mathrm{mmol})$, acetonitrile (45 mL), and 4-methoxybenzyl chloride $(0.86 \mathrm{~mL}$, $6.38 \mathrm{mmol}$ ) were added to a $100 \mathrm{~mL}$ flask. The mixture was kept under stirring and reflux for $18 \mathrm{~h}$. The solvent was evaporated under reduced pressure and the residue was purified by column chromatography in an increasing polarity gradient of $\mathrm{CH}_{2} \mathrm{Cl}_{2}$ and $\mathrm{CH}_{3} \mathrm{OH}(95: 5,90: 10$ and 80:20), affording Wittig salt 3 as a white solid in $97 \%$ yield; mp 236.3-237.6 ${ }^{\circ} \mathrm{C}$; IR (film) v / $\mathrm{cm}^{-1} 3652,3297,2782$, 1634, 1601, 1503, 1433, 1241, 1172, 1106, 1021, 996, 845, 743, 714, 681; ${ }^{1} \mathrm{H}$ NMR (200 MHz, $\left.\mathrm{CDCl}_{3}\right) \delta$ 7.89-7.53 $(\mathrm{m}, 15 \mathrm{H}), 6.98$ (dd, J 7.2, 2.6 Hz, 2H), 6.63 (d, J 8.1 Hz, 2H), 5.24 (d, J $13.7 \mathrm{~Hz}, 2 \mathrm{H}), 3.71(\mathrm{~s}, 3 \mathrm{H}) ;{ }^{13} \mathrm{C} \mathrm{NMR}$ $\left(50 \mathrm{MHz}, \mathrm{CDCl}_{3}\right) \delta 159.67,134.99(\mathrm{~d}, J 1.55 \mathrm{~Hz}), 134.32$ (d, J 9.6 Hz), 132.61 (d, J 5.3 Hz), 118.73, 117.04 (d, $J 84.5 \mathrm{~Hz}), 114.27$ (d, J 2.9 Hz), 55.27, 30.03 (d, J 46.1 Hz); HRMS (ESI-TOF) $\mathrm{m} / \mathrm{z}$, calcd. for $\mathrm{C}_{26} \mathrm{H}_{24} \mathrm{OPCl}[\mathrm{M}-\mathrm{Cl}]^{+}$: 383.1559; found: 383.1551 .

\section{(S,Z)-2,2-Diethyl-4-(4-methoxystyryl)-1,3-dioxolane (4)}

Anhydrous $\mathrm{CH}_{2} \mathrm{Cl}_{2}(16 \mathrm{~mL})$, the Wittig salt (3) (1.80 g, $4.29 \mathrm{mmol})$, and anhydrous tert-butanol (4 mL) were added to a $100 \mathrm{~mL}$ flask containing $(R)$-glyceraldehyde ketal (2) $(0.526 \mathrm{~g}, 3.33 \mathrm{mmol})$. The mixture was stirred vigorously; then, a solution of potassium tert-butoxide $(0.481 \mathrm{~g}$, $4.29 \mathrm{mmol})$ in anhydrous tert-butanol $(4 \mathrm{~mL})$ was added dropwise. The mixture was stirred at room temperature for $1 \mathrm{~h}$ and diluted in dichloromethane $(10 \mathrm{~mL})$ and distilled water $(15 \mathrm{~mL})$. The organic phase was separated and the aqueous phase was extracted with dichloromethane $(3 \times 10 \mathrm{~mL})$. The combined organic phases were washed with saturated $\mathrm{NaCl}$ solution $(10 \mathrm{~mL})$, dried over anhydrous $\mathrm{Na}_{2} \mathrm{SO}_{4}$, and concentrated under reduced pressure. The residue was purified using column chromatography (hexane/EtOAc 95:5) to give the $E$ - and Z-olefins as clear and colorless viscous oils in 17 and $68 \%$ yield, respectively (three steps from D-mannitol).
Data for Z-olefin 4

$[\alpha]_{\mathrm{D}}^{25.5}-5.45^{\circ}\left(c 1.1, \mathrm{CHCl}_{3}\right)$; IR (film) $\mathrm{v} / \mathrm{cm}^{-1} 2972$, 2937, 2881, 1728, 1606, 1510, 1461, 1356, 1251, 1170, 1074, 1031, 914, 841, 766; ${ }^{1} \mathrm{H}$ NMR (400 MHz, $\mathrm{CDCl}_{3}$ ) $\delta 7.22(\mathrm{~d}, J 8.4 \mathrm{~Hz}, 2 \mathrm{H}), 6.87(\mathrm{~d}, J 8.2 \mathrm{~Hz}, 2 \mathrm{H}), 6.65$ (d, $J 11.5 \mathrm{~Hz}, 1 \mathrm{H}), 5.59$ (t, $J 10.3 \mathrm{~Hz}, 1 \mathrm{H}), 4.94-4.85$ (m, 1H), 4.15 (t, J 7.0 Hz, 1H), 3.80 (s, 3H), 3.61 (t, J 8.0 Hz, 1H), 1.76-1.56 (m, 4H), 1.00-0.83 (m, 6H) ${ }^{13} \mathrm{C}$ NMR (100 MHz, $\left.\mathrm{CDCl}_{3}\right) \delta 159.28,133.96,130.20,129.02,127.53,113.89$, 113.41, 72.95, 70.50, 55.40, 30.22, 30.06, 8.41, 8.16; HRMS (ESI-TOF) $\mathrm{m} / z$, calcd. for $\mathrm{C}_{16} \mathrm{H}_{23} \mathrm{O}_{3}[\mathrm{M}+\mathrm{Na}]^{+}$: 263.1647; found: 263.1695 .

\section{Data for E-olefin 4}

${ }^{1} \mathrm{H}$ NMR (400 MHz, $\left.\mathrm{CDCl}_{3}\right) \delta 7.32(\mathrm{~d}, J 8.7 \mathrm{~Hz}, 2 \mathrm{H})$, 6.84 (d, J 8.7 Hz, 2H), 6.61 (d, J $15.8 \mathrm{~Hz}, 1 \mathrm{H}), 5.99$ (dd, $J$ 15.8, $7.8 \mathrm{~Hz}, 1 \mathrm{H}), 4.70-4.58(\mathrm{~m}, 1 \mathrm{H}), 4.14$ (dd, J 8.0, $6.1 \mathrm{~Hz}, 1 \mathrm{H}), 3.80$ (s, 3H), $3.63(\mathrm{t}, J 8.1 \mathrm{~Hz}, 1 \mathrm{H}), 1.76-1.62$ (m, 4H), 0.99-0.90 (m, 6H).

(1S,2S)-1-[(4R)-2,2-Diethyl-1,3-dioxolan-4-yl]-2-(4-methoxyphenyl)ethane-1,2-diol (5)

4-Methylmorpholine $N$-oxide $(0.199 \mathrm{~g}, 1.7 \mathrm{mmol})$ and an aqueous solution $(0.3 \mathrm{~mL})$ of osmium tetroxide $(0.011 \mathrm{~g}$, $0.044 \mathrm{mmol})$ were added to a $100 \mathrm{~mL}$ flask containing a solution of olefin $4(0.390 \mathrm{~g}, 1.48 \mathrm{mmol})$ in acetone (13 mL) and $\mathrm{H}_{2} \mathrm{O}(1.7 \mathrm{~mL})$. The mixture was stirred at room temperature for $3 \mathrm{~h}$. Subsequently, the mixture was treated with saturated sodium sulfite solution and kept under stirring for $10 \mathrm{~min}$. The system was diluted with $\mathrm{H}_{2} \mathrm{O}(10 \mathrm{~mL})$ and extracted with $\mathrm{CH}_{2} \mathrm{Cl}_{2}(3 \times 10 \mathrm{~mL})$. The organic phases were combined, dried over anhydrous $\mathrm{Na}_{2} \mathrm{SO}_{4}$, and concentrated under reduced pressure. The residue was purified by column chromatography (hexane/ ethyl acetate 75:25) affording the syn- and anti-diols (5) as transparent and colorless viscous oils in 12 and $72 \%$ yield, respectively.

\section{Data for anti-diol 5}

$[\alpha]_{\mathrm{D}}{ }^{26.4}+0.83^{\circ}\left(c 1.2, \mathrm{CH}_{3} \mathrm{OH}\right)$; IR (film) $v / \mathrm{cm}^{-1} 3439$, 2972, 2939, 2883, 1610, 1510, 1462, 1247, 1173, 1076, 1032, 913, 831; ${ }^{1} \mathrm{H}$ NMR (400 MHz, $\left.\mathrm{CDCl}_{3}\right) \delta 7.30$ (d, $J 8.6 \mathrm{~Hz}, 2 \mathrm{H}), 6.88$ (d, J $8.6 \mathrm{~Hz}, 2 \mathrm{H}), 4.73$ (d, J $5.6 \mathrm{~Hz}$, $1 \mathrm{H}), 4.04-3.97$ (m, 1H), 3.89-3.82 (m, 2H), 3.79 (s, 3H), $3.21(\mathrm{~s}, 1 \mathrm{H}), 2.22$ (d, J 3.2 Hz, 1H), 1.67 (dq, J 7.4, 3.0 Hz, 2H), 1.58 (q, J 7.4 Hz, 2H), $0.92(\mathrm{t}, J 7.4 \mathrm{~Hz}, 3 \mathrm{H}), 0.86$ $(\mathrm{t}, J 7.4 \mathrm{~Hz}, 3 \mathrm{H}) ;{ }^{13} \mathrm{C} \mathrm{NMR}\left(100 \mathrm{MHz}, \mathrm{CDCl}_{3}\right) \delta 159.67$, 131.86, 128.40, 114.05, 113.30, 76.98, 75.53, 75.22, 67.39, 55.43, 29.73, 29.20, 8.34, 8.21; HRMS (ESI-TOF) $m / z$, calcd. for $\mathrm{C}_{16} \mathrm{H}_{24} \mathrm{NaO}_{5}[\mathrm{M}+\mathrm{Na}]^{+}: 319.1521$; found: 319.1515 . 


\section{Data for syn-diol 5}

${ }^{1} \mathrm{H} \mathrm{NMR}\left(400 \mathrm{MHz}, \mathrm{CDCl}_{3}\right) \delta 7.27$ (d, $\left.J 8.6 \mathrm{~Hz}, 2 \mathrm{H}\right)$, 6.89 (d, J $8.6 \mathrm{~Hz}, 2 \mathrm{H}), 4.79$ (t, J $5.2 \mathrm{~Hz}, 1 \mathrm{H}), 4.16-4.06$ $(\mathrm{m}, 1 \mathrm{H}), 3.89-3.82(\mathrm{~m}, 2 \mathrm{H}), 3.79(\mathrm{~s}, 3 \mathrm{H}), 3.80-3.74(\mathrm{~m}$, 1H), 3.65 (q, J $5.2 \mathrm{~Hz}, 1 \mathrm{H}), 3.59$ (t, J 8.0 Hz, 1H), 3.09 (d, J $5.5 \mathrm{~Hz}, 1 \mathrm{H}), 2.77(\mathrm{~d}, J 6.0 \mathrm{~Hz}, 1 \mathrm{H}), 1.66(\mathrm{dq}, J 7.4$, $2.7 \mathrm{~Hz}, 2 \mathrm{H}), 1.58$ (q, J 7.4 Hz, 2H), 0.91 (t, J 7.4 Hz, 3H), $0.85(\mathrm{t}, J 7.4 \mathrm{~Hz}, 3 \mathrm{H})$.

(1S,2R)-2-Azido-1-[(R)-2,2-diethyl-1,3-dioxolan-4-yl]2-(4-methoxyphenyl)ethanol (7)

Dichloromethane solution $(0.4 \mathrm{~mL})$ of thionyl chloride (0.039 mL, $0.54 \mathrm{mmol})$ was added to a $25 \mathrm{~mL}$ flask containing diol $5(0.139 \mathrm{~g}, 0.46 \mathrm{mmol})$, triethylamine $(0.28 \mathrm{~mL}, 2.0 \mathrm{mmol})$ and $\mathrm{CH}_{2} \mathrm{Cl}_{2}(2 \mathrm{~mL})$ at $0{ }^{\circ} \mathrm{C}$. The mixture was kept under stirring at $0{ }^{\circ} \mathrm{C}$ for $30 \mathrm{~min}$. The mixture was then diluted with ethyl ether $(10 \mathrm{~mL})$ and washed with ice water $(10 \mathrm{~mL})$ and saturated $\mathrm{NaCl}$ solution (10 mL). The organic phases were combined, dried over anhydrous $\mathrm{Na}_{2} \mathrm{SO}_{4}$, and concentrated, yielding sulfite $\mathbf{6}$ as a reddish oil in $79 \%$ yield. The product was used in the next step without further purification because of its high reactivity. DMF $(3 \mathrm{~mL})$ and $\mathrm{NaN}_{3}(0.056 \mathrm{~g}, 0.86 \mathrm{mmol})$ were added to a $25 \mathrm{~mL}$ flask containing sulfite $6(0.166 \mathrm{~g}$, $0.48 \mathrm{mmol})$. The mixture was stirred under an inert atmosphere for $2 \mathrm{~h}$ at $100^{\circ} \mathrm{C}$. After this period, the mixture was cooled in an ice bath, treated with $\mathrm{H}_{2} \mathrm{O}(5 \mathrm{~mL})$, and extracted with ethyl ether $(3 \times 5 \mathrm{~mL})$. The organic phases were combined, washed with saturated $\mathrm{NaCl}$ solution (10 mL), dried over anhydrous $\mathrm{Na}_{2} \mathrm{SO}_{4}$ and concentrated under reduced pressure. The crude residue was purified by column chromatography (hexane/EtOAc 95:5 and 90:10), affording azido alcohol 7 as a yellow oil in $56 \%$ yield (two steps). $[\alpha]_{\mathrm{D}}^{26.4}-69.17^{\circ}\left(c 1.2, \mathrm{CH}_{3} \mathrm{OH}\right.$ ); IR (film) $v / \mathrm{cm}^{-1} 3421,2978,2937,2899,2109,1616,1512,1471$, 1247, 1176, 1075, 1031, 911, 777; ' $\mathrm{H}$ NMR (400 MHz, $\left.\mathrm{CDCl}_{3}\right) \delta 7.30(\mathrm{~d}, J 8.6 \mathrm{~Hz}, 2 \mathrm{H}), 6.92(\mathrm{~d}, J 8.6 \mathrm{~Hz}, 2 \mathrm{H})$, $4.71(\mathrm{~d}, J 3.9 \mathrm{~Hz}, 1 \mathrm{H}), 4.08-3.87(\mathrm{~m}, 3 \mathrm{H}), 3.82(\mathrm{~s}, 3 \mathrm{H})$, 3.79-3.67 (m, 1H), $2.15(\mathrm{~d}, J 6.3 \mathrm{~Hz}, 1 \mathrm{H}), 1.71-1.53(\mathrm{~m}$, $4 \mathrm{H}), 0.97-0.80(\mathrm{~m}, 6 \mathrm{H}) ;{ }^{13} \mathrm{C} \mathrm{NMR}\left(100 \mathrm{MHz}, \mathrm{CDCl}_{3}\right)$ $\delta 160.02,129.70,128.89,114.57,113.49,75.00,75.66$, 66.62, 66.45, 55.52, 29.64, 29.22, 8.45, 8.21; HRMS (ESITOF) $m / z$, calcd. for $\mathrm{C}_{16} \mathrm{H}_{23} \mathrm{~N}_{3} \mathrm{NaO}_{4}[\mathrm{M}+\mathrm{Na}]^{+}: 344.1586$; found: 344.1585 .

(1S,2R)-2-Amino-1-[(R)-2,2-diethyl-1,3-dioxolan-4-yl]2-(4-methoxyphenyl)ethanol (8)

Azido alcohol 7 (0.90 g, $0.28 \mathrm{mmol})$, triphenylphosphine (0.14 g, $0.56 \mathrm{mmol})$, THF (1 mL), and distilled water $(0.5 \mathrm{~mL})$ were added to a $25 \mathrm{~mL}$ flask. The reaction mixture was stirred for $12 \mathrm{~h}$ at $50{ }^{\circ} \mathrm{C}$. Then, the solvents were removed under reduced pressure and the residue was purified by column chromatography (EtOAc/petroleum ether 75:25), affording amino alcohol $\mathbf{8}$ as a white solid in $92 \%$ yield. $[\alpha]_{\mathrm{D}}{ }^{26.7}+5.0^{\circ}\left(c 0.6, \mathrm{CH}_{3} \mathrm{OH}\right) ; \mathrm{mp} 94.8-95.6^{\circ} \mathrm{C}$; IR (film) $\mathrm{v} / \mathrm{cm}^{-1} 3365,2968,2939,2890,1614,1510,1462$, 1232, 1173, 1076, 1032, 909, 831; ${ }^{1} \mathrm{H}$ NMR (400 MHz, $\left.\mathrm{CDCl}_{3}\right) \delta 7.25(\mathrm{~d}, J 8.6 \mathrm{~Hz}, 2 \mathrm{H}), 6.87$ (d, $\left.J 8.6 \mathrm{~Hz}, 2 \mathrm{H}\right)$, 4.05-3.96 (m, 2H), 3.94-3.84 (m, 2H), $3.79(\mathrm{~s}, 3 \mathrm{H})$, 3.78-3.74 (m, 1H), $3.71(\mathrm{t}, J 5.0 \mathrm{~Hz}, 1 \mathrm{H}), 2.25(\mathrm{~s}, 3 \mathrm{H})$, $1.73-1.61(\mathrm{~m}, 2 \mathrm{H}), 1.57$ (q, J 7.4 Hz, 2H), $0.91(\mathrm{t}, J 7.4 \mathrm{~Hz}$, $3 \mathrm{H}), 0.85(\mathrm{t}, J 7.4 \mathrm{~Hz}, 3 \mathrm{H}) ;{ }^{13} \mathrm{C} \mathrm{NMR}\left(100 \mathrm{MHz}, \mathrm{CDCl}_{3}\right)$ $\delta$ 159.21, 134.87, 128.12, 114.23, 113.07, 76.56, 75.60, $66.37,55.87,55.47,29.64,29.15,8.47,8.24$; HRMS (ESI-TOF) $m / z$, calcd. for $\mathrm{C}_{16} \mathrm{H}_{26} \mathrm{NO}_{4}[\mathrm{M}+\mathrm{Na}]^{+}: 296.1862$; found: 296.1858 .

(4R,5S)-5-[(1R)-1,2-Dihydroxyethyl]-4-(4-methoxyphenyl)1,3-oxazolidin-2-one (9)

An aqueous solution of $0.25 \mathrm{~mol} \mathrm{~L}^{-1} \mathrm{NaOH}(4.5 \mathrm{~mL})$ was added to a $25 \mathrm{~mL}$ flask containing amino alcohol 8 $(0.082 \mathrm{~g}, 0.28 \mathrm{mmol})$ dissolved in distilled water $(2 \mathrm{~mL})$ and ethyl ether $(3 \mathrm{~mL})$ at $0{ }^{\circ} \mathrm{C}$. The mixture was stirred for $10 \mathrm{~min}$ at $0{ }^{\circ} \mathrm{C}$, and triphosgene $(0.127 \mathrm{~g}, 0.43 \mathrm{mmol})$ was added. The mixture was stirred for $1.5 \mathrm{~h}$ at the same temperature. At the end of this period, the solvents were evaporated under reduced pressure and the residue was purified by column chromatography (dichloromethane/ methanol 9.5:0.5 and 9:1) to provide oxazolidinone derivative 9 as a white solid in $86 \%$ yield; $[\alpha]_{\mathrm{D}}^{26.7}+24.56^{\circ}$ (c $0.57, \mathrm{CH}_{3} \mathrm{OH}$ ); mp 81.2-82.2 ${ }^{\circ} \mathrm{C}$; IR (film) $\mathrm{v} / \mathrm{cm}^{-1}$ 3328, 2935, 1733, 1692, 1610, 1514, 1425, 1384, 1299, $1243,1176,1028,831 ;{ }^{1} \mathrm{H}$ NMR (400 MHz, acetone- $\left.d_{6}\right)$ $\delta 7.23(\mathrm{~d}, J 8.7 \mathrm{~Hz}, 2 \mathrm{H}), 6.87(\mathrm{~d}, J 8.7 \mathrm{~Hz}, 2 \mathrm{H}), 4.83(\mathrm{~d}$, $J 4.8 \mathrm{~Hz}, 1 \mathrm{H}), 4.39-4.32$ (m, 1H), 4.22 (t, J 4.92, 1H), 3.70 (s, 3H), 3.60-3.46 (m, 2H); ${ }^{13} \mathrm{C} \mathrm{NMR}$ (100 MHz, acetone- $d_{6}$ ) $\delta$ 160.54, 158.89, 135.19, 128.60, 115.04, 84.53, 73.48, 63.36, 57.26, 55.68; HRMS (ESI-TOF) $\mathrm{m} / \mathrm{z}$, calcd. for $\mathrm{C}_{12} \mathrm{H}_{16} \mathrm{NO}_{5}[\mathrm{M}+\mathrm{H}]^{+}:$254.1028; found: 254.1024 .

(4R,5S)-5-(Hydroxymethyl)-4-(4-methoxyphenyl)oxazolidin2-one (1)

To a $50 \mathrm{~mL}$ flask containing oxazolidinone $\mathbf{9}(0.033 \mathrm{~g}$, $0.135 \mathrm{mmol})$, tetrabutylammonium fluoride $(0.0007 \mathrm{~g}$, $0.0029 \mathrm{mmol})$, ethyl ether $(0.5 \mathrm{~mL})$, and distilled water $(0.25 \mathrm{~mL})$, sodium periodate $(0.062 \mathrm{~g}, 0.27 \mathrm{mmol})$ was added in small portions. The mixture was maintained under stirring at room temperature for $1 \mathrm{~h}$. A saturated aqueous solution of $\mathrm{NaHCO}_{3}(2 \mathrm{~mL})$ was then added and extracted with ethyl acetate $(3 \times 5 \mathrm{~mL})$. The combined organic phases were washed with saturated $\mathrm{NaCl}$ solution, dried over anhydrous $\mathrm{Na}_{2} \mathrm{SO}_{4}$, and concentrated under reduced pressure 
to provide the respective aldehyde. The aldehyde was used in the next step without prior purification. Anhydrous methanol $(1 \mathrm{~mL})$ was added to the flask containing the corresponding aldehyde $(0.029 \mathrm{~g}, 0.135 \mathrm{mmol})$ and the system was cooled to $0{ }^{\circ} \mathrm{C}$. Subsequently, $\mathrm{NaBH}_{4}(0.0061 \mathrm{~g}$, $0.162 \mathrm{mmol}$ ) was added. The mixture was stirred for $10 \mathrm{~min}$ at the same temperature and then for $1 \mathrm{~h}$ at room temperature. At the end of this period, distilled water $(5 \mathrm{~mL})$ was added and the mixture was extracted with ethyl acetate $(3 \times 5 \mathrm{~mL})$. The organic phases were combined, dried over anhydrous $\mathrm{Na}_{2} \mathrm{SO}_{4}$, and concentrated under reduced pressure. The residue was purified by column chromatography (ethyl acetate/petroleum ether 7.5:2.5 and 9:1), affording 5-epi-cytoxazone (1) as a white solid in 79\% yield (two steps); $[\alpha]_{D}{ }^{26.7}+27.5^{\circ}\left(c 0.4, \mathrm{CH}_{3} \mathrm{OH}\right) ;\left\{\right.$ lit. ${ }^{13,24-26}$ $[\alpha]_{\mathrm{D}}{ }^{25}+28.8^{\circ}\left(c 0.59, \mathrm{CH}_{3} \mathrm{OH}\right),[\alpha]_{\mathrm{D}}{ }^{25}+32^{\circ}(c 0.4, \mathrm{MeOH})$, $[\alpha]_{\mathrm{D}}{ }^{25}+22.89^{\circ}\left(c\right.$ o.4, $\left.\left.\mathrm{CH}_{3} \mathrm{OH}\right)\right\} ; \mathrm{mp} 161.3-162.3{ }^{\circ} \mathrm{C}$; IR (film) $v / \mathrm{cm}^{-1} 3250,3142,2963,2925,2854,1724,1616$, 1508, 1415, 1247, 1094, 1023, 829; ${ }^{1} \mathrm{H}$ NMR $(400 \mathrm{MHz}$, acetone- $\left.d_{6}\right) \delta 7.33(\mathrm{~d}, J 8.7 \mathrm{~Hz}, 2 \mathrm{H}), 6.95(\mathrm{~d}, J 8.7 \mathrm{~Hz}, 2 \mathrm{H})$, $4.78(\mathrm{~d}, J 6.4 \mathrm{~Hz}, 1 \mathrm{H}), 4.35$ (t, $J 6.0 \mathrm{~Hz}, 1 \mathrm{H}), 4.29-4.21$ $(\mathrm{m}, 1 \mathrm{H}), 3.86-3.80(\mathrm{~m}, 1 \mathrm{H}), 3.79(\mathrm{~s}, 3 \mathrm{H}), 3.75-3.66(\mathrm{~m}$, $1 \mathrm{H}) ;{ }^{13} \mathrm{C}$ NMR $\left(100 \mathrm{MHz}\right.$, acetone- $\left.d_{6}\right) \delta 160.71,159.13$, 133.98, 128.49, 115.13, 85.69, 62.52, 57.76, 55.68; HRMS (ESI-TOF) $m / z$, calcd. for $\mathrm{C}_{11} \mathrm{H}_{14} \mathrm{NO}_{4}[\mathrm{M}+\mathrm{H}]^{+}: 224.0917$; found: 224.0918 .

\section{Supplementary Information}

Supplementary data $\left({ }^{1} \mathrm{H},{ }^{13} \mathrm{C}\right.$ NMR and mass spectra) associated with this article are available free of charge at http://jbcs.sbq.org.br as PDF file.

\section{Acknowledgments}

We thank FAPEMIG, MG, Brazil, for the grant awarded to G. D.-M. (APQ-01061-14), PRPq-UFMG for the partial support, CAPES for the doctoral scholarship awarded to I. L. M., and Betania B. Cota of the René Rachou Research Center, Fiocruz, MG, for the specific rotation analyses.

\section{References}

1. Sood, R.; Bhadauriya, T.; Rao, M.; Gautam, R.; Malhotra, S.; Barman, T. K.; Upadhyay, D. J.; Infect. Disord.: Drug Targets 2006, 6, 343.

2. Bozdogan, B.; Appelbaum, P. C.; Int. J. Antimicrob. Agents 2004, 23, 113.

3. Muller, M.; Schimz, K. L.; Cell. Mol. Life Sci. 1999, 56, 280.

4. Marchese, A.; Schito, G. C.; Clin. Microbiol. Infect. 2001, 7, 66.
5. Zappia, G.; Gacs-Baitz, E.; Monache, G. D.; Misiti, D.; Nevola, L.; Botta, B.; Curr. Org. Synth. 2007, 4, 81.

6. Kakeya, H.; Morishita, M.; Kobinata, K.; Osono, M.; Ishizuka, M.; Osada, H.; J. Antibiot. 1998, 51, 1126.

7. Sakamoto, Y.; Shiraishi, A.; Seonhee, J.; Nakata, T.; Tetrahedron Lett. 1999, 40, 4203.

8. Seki, M.; Mori, K.; Eur. J. Org. Chem. 1999, 11, 2965.

9. Kakeya, H.; Morishita, H.; Koshino, T.; Morita, K.; Kobayashi, K.; Osada, H.; J. Org. Chem. 1999, 64, 1052.

10. Miranda, I. L.; Lopes, I. K. B.; Diaz, M. A. N.; Diaz, G.; Molecules 2016, 21, 1176.

11. Wu, H.; Haeffner, F.; Hoveyda, A. H.; J. Am. Chem. Soc. 2014, 10,3780 .

12. Lu, L.-Q.; Cao, Y.-J.; Liu, X.-P.; An, J.; Yao, C.-J.; Ming, Z.-H.; Xiao, E.-J.; J. Am. Chem. Soc. 2008, 22, 6946.

13. Smitha, G.; Reddy, C. S.; Synth. Commun. 2006, 36, 1795.

14. Qian, Y.; Xu, X.; Jiang, L.; Prajapati, D.; Hu, W.; J. Org. Chem. 2010, 75, 7483.

15. Kim, J.; Seo, Y. J.; Kang, S.; Han, J.; Lee, H.-K.; Chem. Commun. 2014, 50, 13706.

16. Matsushima, Y.; Ishikawa, M.; Shibasaki, R.; Nojima, Y.; Tetrahedron Lett. 2018, 59, 231.

17. Kumar, R. A.; Bhaskar, G.; Madhan, A.; Rao, B. V.; Synth. Commun. 2003, 33, 2907.

18. Schmid, C. R.; Bryant, J. D.; Org. Synth. 1995, 72, 6.

19. Diaz-Muñoz, G.; Isidorio, R. G.; Miranda, I. L.; Dias, G. N. S.; Diaz, M. A. N.; Tetrahedron Lett. 2017, 58, 3311.

20. Cha, J. K.; Christ, W. J.; Kishi, Y.; Tetrahedron Lett. 1983, 24 , 3943.

21. Megia-Fernandez, A.; Morales-Sanfrutos, J.; Hernandez-Mateo, F.; Santoyo-Gonzalez, F.; Curr. Org. Chem. 2010, 14, 401.

22. García-Granados, A.; López, P. E.; Melguizo, E.; Moliz, J. N.; Parra, A.; Simeo, Y.; J. Org. Chem. 2003, 68, 4833.

23. Lin, F. L.; Hoyt, H. M.; Halbeek, H. V.; Bergman, R. G.; Bertozzi, C. R.; J. Am. Chem. Soc. 2005, 127, 2686.

24. Hamersak, Z.; Ljubovic, E.; Mercep, M.; Mesic, M.; Sunjic, V.; Synthesis 2001, 13, 1989.

25. Tokic-Vujosevic, Z.; Petrovic, G.; Rakic, B.; Matovic, K.; Saicic, R. N.; Synth. Commun. 2005, 35, 435.

26. Paraskar, A. S.; Sudalai, A.; Tetrahedron 2006, 62, 5756.

27. Hoffman, R. V.; Maslouh, N.; Cervantes-Lee, F.; J. Org. Chem. 2002, 67, 1045.

28. Ciapetti, P.; Taddei, M.; Ulivi, P.; Tetrahedron Lett. 1994, 35 , 3183.

29. Diaz, G.; de Freitas, M. A. A.; Ricci-Silva, M. E.; Diaz, M. A. N.; Molecules 2014, 19, 7429.

30. Kempf, D. J.; J. Org. Chem. 1986, 51, 3921.

31. Schmid, C.; Bradley, D. A.; Synthesis 1992, 6, 587.

Submitted: October 1, 2018

Published online: October 25, 2018 